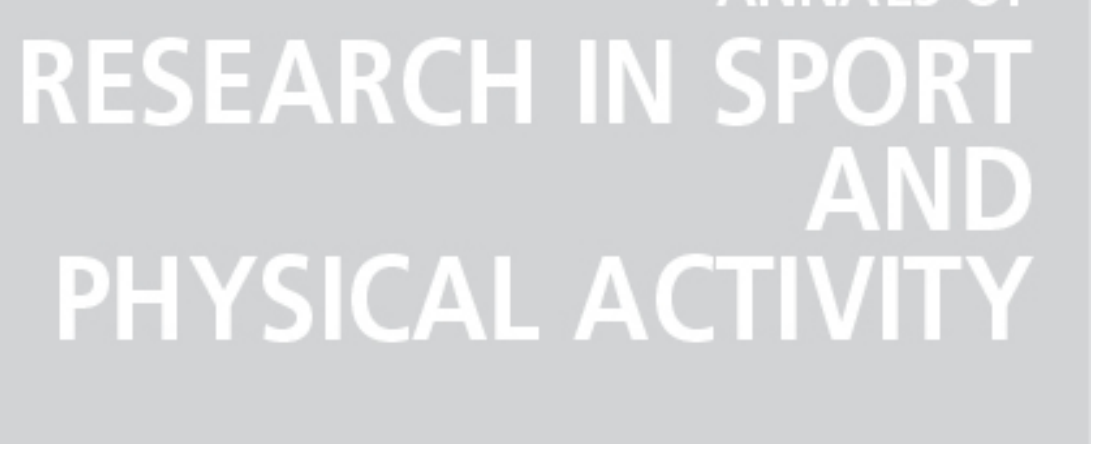

\title{
Scaling of force velocity in young basketball players
}
Autor(es):
Baptista, Rafael J.; Coelho-e-Silva, Manuel; Santos, Amândio C.; Capranica, Laura

Publicado por: Imprensa da Universidade de Coimbra

URL persistente:

URI:http://hdl.handle.net/10316.2/28354

DOI:

DOI:http://dx.doi.org/10.14195/2182-7087_4_6

Accessed : $\quad$ 26-Apr-2023 10:46:20

A navegação consulta e descarregamento dos títulos inseridos nas Bibliotecas Digitais UC Digitalis, UC Pombalina e UC Impactum, pressupõem a aceitação plena e sem reservas dos Termos e Condições de Uso destas Bibliotecas Digitais, disponíveis em https://digitalis.uc.pt/pt-pt/termos.

Conforme exposto nos referidos Termos e Condições de Uso, o descarregamento de títulos de acesso restrito requer uma licença válida de autorização devendo o utilizador aceder ao(s) documento(s) a partir de um endereço de IP da instituição detentora da supramencionada licença.

Ao utilizador é apenas permitido o descarregamento para uso pessoal, pelo que o emprego do(s) título(s) descarregado(s) para outro fim, designadamente comercial, carece de autorização do respetivo autor ou editor da obra.

Na medida em que todas as obras da UC Digitalis se encontram protegidas pelo Código do Direito de Autor e Direitos Conexos e demais legislação aplicável, toda a cópia, parcial ou total, deste documento, nos casos em que é legalmente admitida, deverá conter ou fazer-se acompanhar por este aviso. 

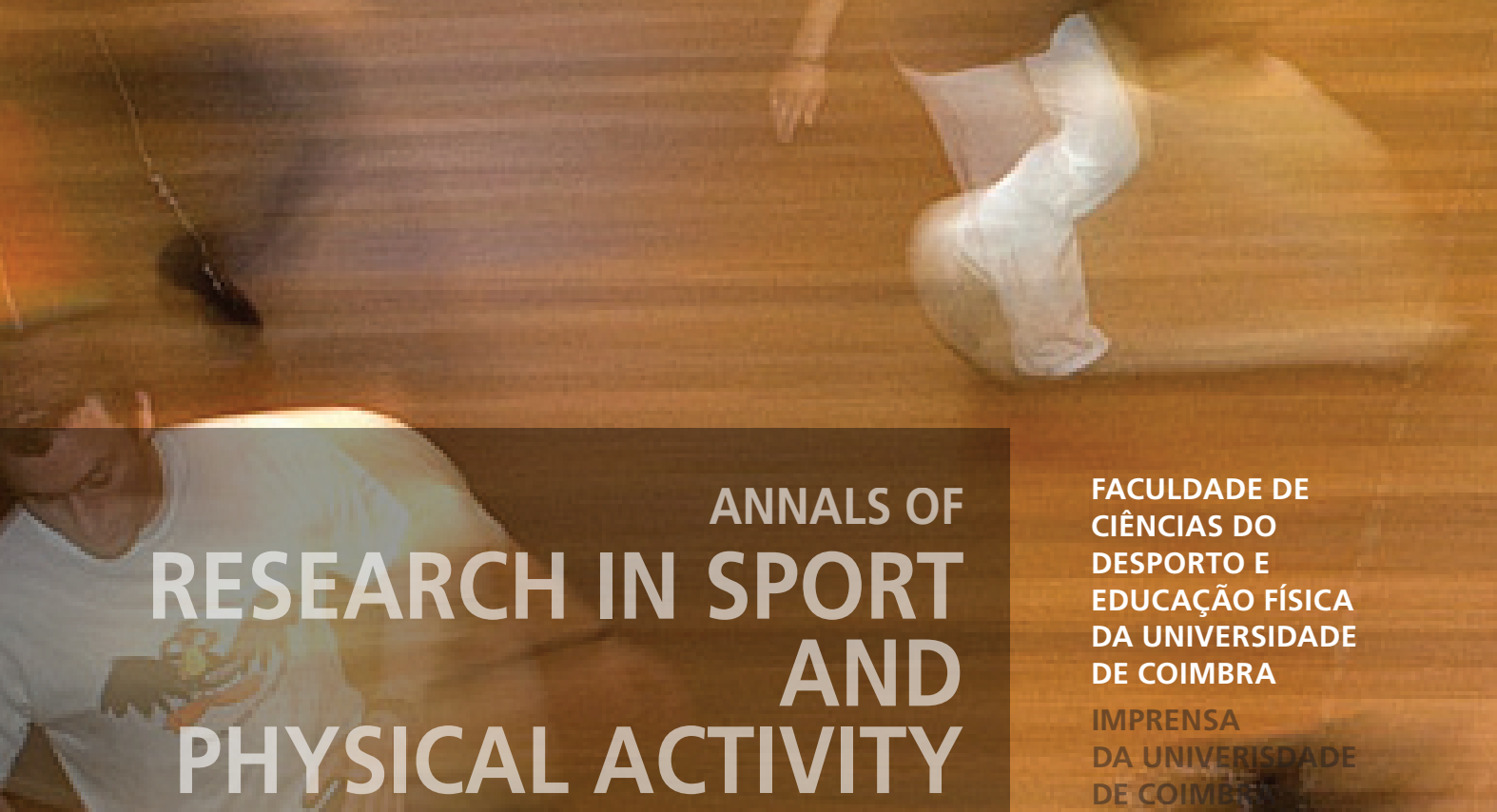
2・ TREINO DESPORTIVO/SPORT TRAINING SCALING OF FORCE VELOCITY IN YOUNG BASKETBALL PLAYERS 
Rafael J. Baptista1', Manuel Coelho-e-Silva', Amândio C. Santos¹, Laura Capranica²

\section{INTRODUCTION}

Run, jump and shoot, are recreational manifestations, spontaneous, made every day by any healthy child or young boy or girl. Playing activities at this age is characterized mainly by sudden and explosive actions.

In addition, basketball it's a game that, in the main actions, always demands short-term maximal efforts, meaning, a product of force by velocity. Literature sources refer body sizes as determinant in short-term maximal performance.

Therefore, the aim of this study was to analyze the relative contributions of the physical characteristics in force-velocity performance in young basketball players, using scaling techniques.

\section{METHODS}

A sample of sixty six boys, from Coimbra (district) divided in two groups, basketball players (experimental) and nonsporting peers (control) all at stage 1 of pubic hair (criteria specified by Tanner): (E 1) prepubertal players ( $n=33$ ) 10,7 y; (C 1) prepubertal nonsporting ( $n=33$ ) 10,8 y.

Anthropometric information about subjects were assessed and included: heights, weight, skinfolds and circumferences. Body composition and proportions were estimated.

Peak power (PP opt) and associated measures (F opt and V opt), was assessed by a forcevelocity test in cycle ergometer Monark 824E.

Descriptive statistics for the total sample $(n=66)$ were computed; a normality test was made. Correlations between short-term maximal efforts performances variables (Force Velocity test output) and size descriptors were used to examine relationships between somatic characteristics and performances.

Allometric model enabled parameters in the allometric equation to identify relationships between stature, leg length, body mass, fat free mass and lower limb volume, with shortterm maximal efforts measurements: optimal load and Force Velocity test output.

Multiplicative allometric models [Log (optimal load or FVT output) $=k$. log (Xi, size descriptor) $+a+b(Z i, C A$ or $A P H V)+\log E]$ combining one size descriptor (Xi) with

\footnotetext{
${ }^{1}$ Faculty of Sport Sciences and Physical Education, University of Coimbra, Portugal

2 Department of Human Movement and Sport Sciences, University of Rome "Foro Italico,", Rome, Italy.
} 
chronological age (CA) or age at peak height velocity (APHV) (Zi) were used to explain variance on the FVT output and variance on the optimal load.

\section{RESULTS}

Correlations between optimal load and size descriptors: stature, leg length, body mass, fat free mass and lower limb volume; and Force Velocity test output with the same size descriptors are all statistically significant $(p<0.001)$. Scaling analysis provided, also, significant $(p<0.001)$ allometric exponents $(b)$ of performance variables considering different size descriptors.

Multiplicative allometric models displays significant $(p<0.001)$ contributions of the all size descriptors combined with CA and APHV on FVT performances; However, fat free mass presents the most significant values.

\section{DISCUSSION}

Data reveled that all size descriptors seem to be determinant on the short-term maximal efforts. Nevertheless, considering CA or APHV fat free mass appears to be the size descriptor that contributes more for the variance of the FVT performance.

\section{REFERENCES}

Armstrong, N., Welsman, J., Williams, C. e Kirby, B. (2000). Longitudinal Changes in Young People's ShortTerm Power Output. Medicine and Science in Sports and Exercise. 32 (6): 1140-1145.

Barry, AJ and Cureton, TK (1961). Factorial analysis of physique and performance in prepubescent boys. Res Q 32: 283-300,.

Batterham, AM and George, KP. (1997). Allometric modeling does not determine a dimensionless power function ratio for maximal muscular function. J Appl Physiol 83: 2158-2166.

Nevill, A.M., A.D. Stewart, T. Olds, and R.L. Holder (2004). Are adult physiques geometrically similar? The dangers of allometric scaling using body mass power laws. Am. J. Phys. Anthropol. 124:177-182.

Van Praagh, E and Dore, E. (2002). Short-term muscle power during growth and maturation. Sports Med 32: 701-728. 